\title{
Estimated crop loss due to coconut mite and financial analysis of controlling the pest using the acaricide abamectin
}

\author{
Daniela Rezende ${ }^{1} \cdot$ José W. S. Melo $^{2}$ José E. M. Oliveira ${ }^{3}$ • \\ Manoel G. C. Gondim Jr. ${ }^{1}$
}

Received: 7 November 2015/Accepted: 31 March 2016/Published online: 8 April 2016

(C) Springer International Publishing Switzerland 2016

\begin{abstract}
Reducing the losses caused by Aceria guerreronis Keifer has been an arduous task for farmers. However, there are no detailed studies on losses that simultaneously analyse correlated parameters, and very few studies that address the economic viability of chemical control, the main strategy for managing this pest. In this study the objectives were (1) to estimate the crop loss due to coconut mite and (2) to perform a financial analysis of acaricide application to control the pest. For this, the following parameters were evaluated: number and weight of fruits, liquid albumen volume, and market destination of plants with and without monthly abamectin spraying (three harvests). The costs involved in the chemical control of $A$. guerreronis were also quantified. Higher A. guerreronis incidence on plants resulted in a $60 \%$ decrease in the mean number of fruits harvested per bunch and a $28 \%$ decrease in liquid albumen volume. Mean fruit weight remained unaffected. The market destination of the harvested fruit was also affected by higher A. guerreronis incidence. Untreated plants, with higher A. guerreronis infestation intensity, produced a lower proportion of fruit intended for fresh market and higher proportions of non-marketable fruit and fruit intended for industrial processing. Despite the costs involved in controlling A. guerreronis, the difference between the profit from the treated site and the untreated site was 18,123.50 Brazilian Real; this value represents $69.1 \%$ higher profit at the treated site.
\end{abstract}

Keywords Abamectin - Aceria guerreronis $\cdot$ Cocos nucifera $\cdot$ Economic viability · Production

José W. S. Melo

wagnermelo@hotmail.com; wagnermelo@ufc.br

1 Programa de Pós-Graduação em Entomologia Agrícola, Departamento de Agronomia/Entomologia, Universidade Federal Rural de Pernambuco, Rua Dom Manoel de Medeiros s/n, Dois Irmãos, Recife, PE 52171-900, Brazil

2 Departamento de Fitotecnia - Entomologia, Universidade Federal do Ceará - Campus do Pici, Avenida Mister Hull, n 2977, Bloco 805, Sala 215, Fortaleza, CE CEP 60356-000, Brazil

3 Embrapa Semiárido, Entomologia, Br 428 km 152, Caixa Postal 23, Petrolina, PE 56302-970, Brazil 


\section{Introduction}

Cocos nucifera L. coconut palm is a tropical crop widely distributed in Asia, Africa, and America, farmed on approximately 11.2 million hectares in approximately 90 countries (FAO 2012). It is estimated that $96 \%$ of the global production comes from small-scale farmers with a cultivating land area of $0.2-4$ ha, and $70 \%$ of this production is consumed domestically in producing countries (Martin and Jesus 2011). This palm is important in coconut oil production, as a foreign-exchange generator, and as a subsistence crop for small-scale farmers, supplying food, beverages, fuel, animal feed, and shelter (Foale 2003).

Coconut mite, Aceria guerreronis Keifer (Acari: Eriophyidae), is one of the main pests of this palm in the Americas (Moore et al. 1989; Lawson-Balagbo et al. 2008), Africa (Negloh et al. 2011), and a portion of Asia (Haq et al. 2002; Fernando and Aratchige 2010). Aceria guerreronis colonies are located in the perianth, the fruit's meristematic region, which is covered by bracts (Moore and Howard 1996). Feeding of this pest usually causes triangular white-yellowish patch on the epidermis, which then expand and become necrotic (Moore and Howard 1996; Nair 2002). With fruit growth, longitudinal cracks arise on the necrotic area, and resin exudation, fruit deformation (Cardona and Potes 1971), and abortion can also occur (Doreste 1968; Nair 2002; Wickramananda et al. 2007). Infested fruit by $A$. guerreronis that are not aborted can exhibit reduced fruit weight and size, liquid albumen (coconut water) volume and solid albumen (copra) weight, which decreases its market value (Moore et al. 1989; Haq et al. 2002; Paul and Mathew 2002). There is high variation in the estimated losses caused by A. guerreronis, ranging from 10 to $70 \%$ of production (Doreste 1968; Hernández 1977; Julia and Mariau 1979; Moore et al. 1989; Moore 2000; Seguni 2000; Wickramananda et al. 2007). One of the main reasons for this high variation is the diversity of methods used to quantify the losses, which hinders comparisons between studies (Navia et al. 2013). In the studies performed to date, loss quantification has been limited to a few parameters, which were neither evaluated simultaneously nor correlated with each other, nor were they translated into economic values.

Reducing losses caused by A. guerreronis has been an arduous task for farmers because the pest colonies are difficult to access due to the protected habitat created by the bracts (Moore 2000; Ramaraju et al. 2002; Lawson-Balagbo et al. 2007; Galvão et al. 2011; Lima et al. 2012). Bracts of the fruit act as a physical barrier, hindering the direct action of acaricides on the colony in the perianth (Mariau and Tchibozo 1973; Hernández 1977). Mite mortality occurs through contact with the acaricide during its dispersal (Silva et al. 2013), requiring frequent applications over short time intervals for efficient control (Hernández 1977; Julia and Mariau 1979; Fernando et al. 2002). The need for frequent applications may impair implementation of this method for low-yield farmers due to the high cost (Mariau and Tchibozo 1973; Hernández 1977; Ramaraju et al. 2002). The efficacy of chemical products in A. guerreronis control has been reported in some countries (Mariau and Tchibozo 1973; Cabrera 1991; Muthiah et al. 2001; Moreira and Nascimento 2002; Ramaraju et al. 2002; Fernando and Chandrasiri 2010; Melo et al. 2012), and according to Melo et al. (2012), the interval between spraying of some acaricides, such as abamectin, can be increased, thus reducing control costs. Although some products are efficient, there has been a lack of studies addressing the economic viability of this control strategy.

Currently, Brazil is worldwide the fourth largest coconut producer with an approximate production of 2.8 million tons of coconut in a harvested area of 257 thousand ha (FAO 
2012), and $84 \%$ of this area is located within northeast Brazil (Aragão et al. 2002). The coconut palm crop is adapted to growing in sandy soil along Brazil's northeast coastline, being extensively farmed along the Brazilian coast, and it has been expanding into irrigated areas such as the northeastern semiarid region (Cuenca et al. 2011). The present study reports a detailed survey of the losses caused by A. guerreronis in green dwarf coconut palm in northeast Brazil. The losses caused by A. guerreronis were estimated based on the following parameters: (i) number of fruits harvested/bunch; (ii) mean weight of the fruits harvested/bunch; (iii) mean liquid albumen volume/fruit, and (iv) market destination of the harvested fruit (fresh market, industrial processing, non-marketable). Additionally, an economic analysis of the costs involved in using chemical control was performed.

\section{Materials and methods}

\section{Study site and crop management system}

The study was conducted on a commercial coconut palm plantation (green dwarf variety) with plants that were approximately 17 years old and $5 \mathrm{~m}$ tall in Petrolina, state of Pernambuco (PE), Brazil $\left(08^{\circ} 58^{\prime} \mathrm{S}, 35^{\circ} 11^{\prime} \mathrm{W}\right)$ between March and October 2012. The local climate is BSwh' according to the Köppen classification, indicating an arid climate region (Kottek et al. 2006) with a rainy season concentrated between January and April, strong insolation (2800 h/year), and low relative humidity (below $55 \%$ during the hottest months). During the study, all the plants received the same water volume (300 $\mathrm{L} \mathrm{day}^{-1}$ ) and were fertilised by fertigation [810 g per plant annually for each nutrient: $\mathrm{N}$ (urea) and $\mathrm{K}$ (potassium chloride)]. After the onset of the reproductive phase under sub-optimal farming conditions (the conditions for most crops worldwide), the green dwarf coconut palm usually produces an inflorescence every 30 days. After fertilisation of the flowers, the inflorescences develop bunches which can be harvested 7 months after anthesis. Under the farming conditions of the present study, the time to harvest was reduced from 7 to 4-5 months, and a new inflorescence was emitted within approximately 20 days.

\section{Pre-evaluation of the plants}

To determine the initial levels of damage of A. guerreronis, one group of 20 plants was arbitrarily selected, marked, and divided into two subgroups of ten each. The subgroups were separated by two plant rows, and each of the 20 plants was sampled. For each plant, the six oldest bunches were sampled (assigning a value of zero to the inflorescence and counting the following bunches chronologically). Thereafter, these bunches were referred to as bunches 2, 3, 4, 5, 6, and 7, respectively. Fruits from bunch 1 were not considered as they exhibited no damage (Melo et al. 2012). The mean level of damage caused by A. guerreronis was estimated based on two fruits collected from each bunch (bunches 2 through 6), using the diagrammatic scale described by Galvão et al. (2008). In this scale, the size of the necrotic area caused by A. guerreronis was determined as a proportion of the fruit's total surface (Galvão et al. 2008). The diagrammatic scale is based on 1, 2, 4, 8, 16, 32,48 , and $70 \%$ damage levels. All of the fruits from bunch 7 were collected and used to evaluate the following parameters: (i) number of fruits, (ii) fruit weight, and (iii) liquid albumen volume per fruit. Additionally, these fruits were categorised into three groups according to their market destination: fresh market, industrial processing, and non- 
marketable. To categorise the fruits, they were all visually inspected to determine the necrotic area intensity. Fruits without necrosis were categorised as intended for fresh market, fruits with moderate necrosis (up to $16 \%$ necrotic area) were categorised as intended for industrial processing, and fruits with moderate to high damage (above $16 \%$ necrotic area) were classified as non-marketable (Fig. 1). The data on mean percentage of necrotic area, number of fruits, fruit weight, and liquid albumen volume were subjected to tests of normality (Kolmogorov test) and homogeneity of variance (Bartlett test) and subsequently compared by $t$ test (Pooled method: equality of variance) (PROC TTEST, SAS Institute 2002). The analyses between the fruit categories were performed using the Wilcoxon non-parametric test (PROC Npar1way, SAS Institute 2002).

\section{Evaluation of the losses caused by Aceria guerreronis}

The two previously established plant subgroups received different treatments to evaluate the losses caused by A. guerreronis. One of the subgroups consisted of all of the bunches sprayed with the acaricide abamectin (Vertimec 18CE; Syngenta, Paulínia, Brazil) at the dose recommended by the manufacturer $(9 \mathrm{~g} / \mathrm{ha})$. The acaricide was sprayed onto the developing bunches at monthly intervals. Nothing was applied to the other plant subgroup, allowing for free development of the A. guerreronis populations. The subgroups were separated by two plant rows, and the positions of the two subgroups within the field were oriented according to the wind direction to minimise acaricide drift so that it did not reach the plants with unsprayed bunches. After a four-month interval (the period necessary for the first inflorescence emitted after the first spraying to reach the point of harvest), all of the fruits from bunch 7 were collected in both plant subgroups and were evaluated for the parameters described in the previous section. For logistical limitations, sampling could not be conducted during the whole year (i.e., at monthly intervals); thus, to allow more precise estimates, three samplings were conducted, each one with an interval of four months, evaluating a total of three harvests. The number of fruits per plant, fruit weight per plant, and liquid albumen volume of the fruits per plant were subjected to normality (Kolmogorov: normal test) and homogeneity of variance tests (Bartlett test) and were then subjected to a Generalized Linear Model (GLM) using Wilks' lambda indicator. The treated and untreated plants were compared for each parameter by the Fisher test and
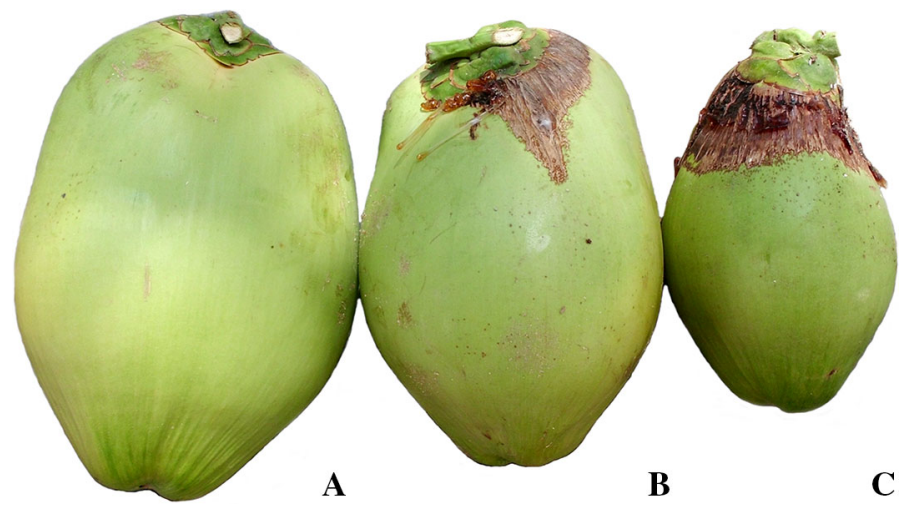

Fig. 1 Fruits categorised as intended for $(A)$ fresh market, $(B)$ industrial processing, and $(C)$ nonmarketable 
within each treatment over time by Tukey's test at $5 \%$ significance with Bonferroni correction. Pearson correlation was used to evaluate the linear relationships between the mean number of fruits per plant, mean fruit weight per plant, and liquid albumen volume of fruits per plant (PROC CORR, SAS Institute 2002). The proportions of fruits in the different categories (fresh market, industrial processing, and non-marketable) were compared with the Wilcoxon non-parametric test (PROC Npar1way, SAS Institute 2002).

\section{Evaluation of the costs associated with chemical control}

To evaluate the cost of chemically controlling A. guerreronis, the cash flow of one hectare of green dwarf coconut palm (205 plants) was estimated within the study site. The costs involved in chemical control included the number of tractor hours (Brazilian Real $[B R L] /$ machine hour, which included all of the costs of fuel, depreciation, equipment maintenance, and labour); daily wages for two persons who helped with the spraying; and purchase of the following inputs: mineral oil $(3.0 \mathrm{~L} / \mathrm{ha})$, which acts as an adjuvant by increasing acaricide absorption, and the acaricide Vertimec $18 \mathrm{CE}(0.5 \mathrm{~L} / \mathrm{ha})$. Profit was estimated for 12 harvests/year, which corresponds to 18 bunches, given that one bunch is emitted every 20 days and harvesting is performed monthly and not exactly when the bunches reach the point of harvest. The costs involved in the total net profit of one hectare/ year refer to a total of 15 sprayings because, after the beginning of the spraying, fruits at the point of harvest are entirely covered by spray only after four months from the first spraying.

\section{Results}

\section{Pre-evaluation of the plants}

There were no significant differences between the plants selected with respect to the parameters evaluated [number of fruits harvested per bunch $(x=21.0 \pm 1.59$, $\left.t_{18}=-0.78, P=0.45\right)$, fruit weight $\left(x=1.7 \pm 0.06 \mathrm{~kg}, t_{18}=0.87, P=0.40\right)$, liquid albumen volume per fruit $\left(x=294.6 \pm 17.75 \mathrm{~mL}, t_{18}=0.49, P=0.63\right)$, proportion of fruits per category (fresh market, $x=0.44 \pm 0.04$ fruit, $\chi^{2}=1.1371, d f=1, P=0.29$; industrial processing, $x=0.51 \pm 0.04$ fruit, $\chi^{2}=2.9170, d f=1, P=0.088$; non-marketable, $x=0.05 \pm 0.02$ fruit, $\left.\chi^{2}=1.0510, d f=1, P=0.31\right)$. The levels of fruit damage also did not differ between the plant subgroups, with fruits showing $10.88 \pm 1.75 \%$ damaged area $\left(\chi^{2}=1.8436, d f=1, P=0.17\right)$, which corresponds to approximately 2700 mites per fruit according to Galvão et al. (2008). Thus, both plant subgroups were equally infested by A. guerreronis before the onset of the experiment.

\section{Evaluation of the losses caused by Aceria guerreronis}

The mean number of fruits per bunch harvested was affected by acaricide spraying $\left(F_{1,18}=100.58, P<0.0001\right)$, whereas no significant effect of time was detected (Wilks' lambda $\left.=0.82, F_{2,17}=1.81, P=0.19\right)$. The interaction between time and spraying was significant (Wilks' lambda $=0.51, F_{2,17}=8.12, P=0.0033$ ). Plants with sprayed bunches always exhibited a higher number of fruits per bunch than the plants with unsprayed bunches (Fig. 2). The number of fruits harvested per bunch within each subgroup (plants 
with sprayed bunches and plants with unsprayed bunches) did not differ throughout the harvests (Fig. 2). No difference was expected within each subgroup, because the monthly variation of the fruit set was not taken into account (samplings were done at 3 nonsuccessive months). The mean number of fruits harvested per bunch ranged from 17.3 to 22.9 in plants with sprayed bunches and from 6.8 to 9.3 in plants with unsprayed bunches. Considering the three harvests together, the number of fruits per bunch decreased by $60 \%$.

Fruit weight remained unaffected by the spraying $\left(F_{1,18}=0.15, P=0.70\right)$; however, it was significantly affected by time (Wilks' lambda $=0.38, F_{2,17}=13.79, P=0.0003$ ). The interaction between time and spraying was not significant (Wilks' lambda $=0.84$, $\left.F_{2,17}=1.54, P=0.24\right)$. There were only significant differences in the untreated plants, which exhibited a high mean at the last harvest $(2.0 \mathrm{~kg})$ compared to the others $(>1.6 \mathrm{~kg})$ $\left(F_{2,27}=7.75, P=0.0022\right)$ (Fig. 3). Fruit weight in the treated plants ranged from 1.6 to $1.9 \mathrm{~kg}\left(F_{2,27}=2.34, P=0.12\right)$ (Fig. 3).

Liquid albumen volume per fruit was affected by the spraying $\left(F_{1,18}=18.38\right.$, $P=0.0004$ ), and there was also a significant effect of time (Wilks' lambda $=0.33$, $\left.F_{2,17}=17.40, P<0.0001\right)$. However, the interaction between time and spraying was not significant (Wilks Lambda $=0.25, F_{2,17}=2.12, P=0.15$ ). During the first and second harvests, the sprayed plants exhibited higher liquid albumen volume per fruit than the unsprayed plants. During the third harvest, there were no significant differences between the plant subgroups (Fig. 4). In both plant subgroups, liquid albumen volume increased throughout the harvests (Fig. 4). Liquid albumen volume per fruit harvested from untreated plants decreased by $28 \%$ considering the three harvests.

The plants with unsprayed bunches exhibited positive correlations between the mean number of fruits per bunch and mean fruit weight per bunch $(r=0.68, n=28$, $P<0.0001$; Fig. 5A) and between the mean number of fruits per bunch and mean liquid

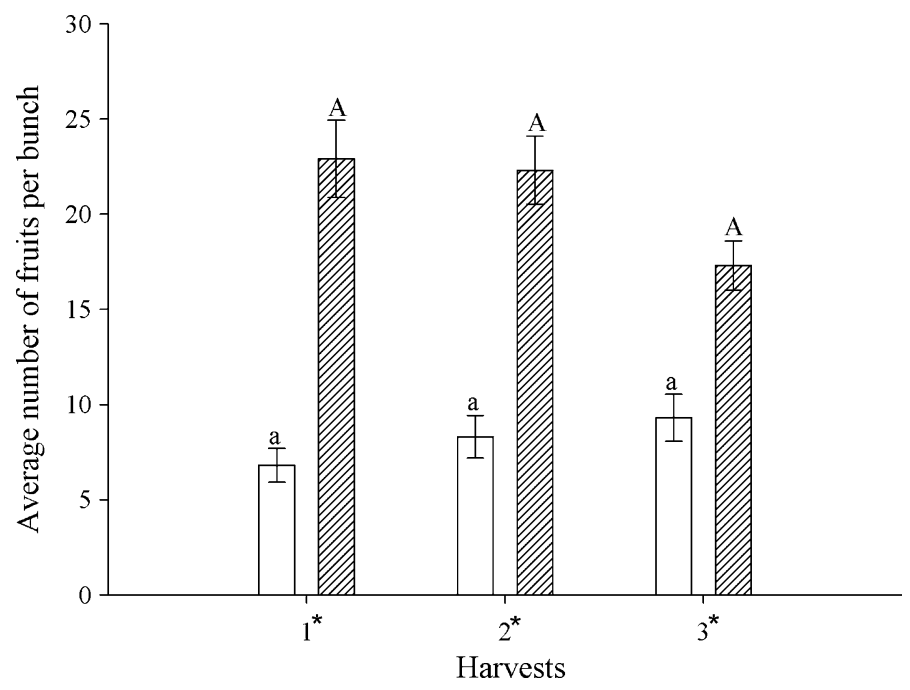

Fig. 2 Mean ( \pm SEM) number of fruits per bunch, at the point of harvest, during 3 non-successive harvests. The white bars represent untreated plants, and the hatched bars represent treated plants. Numbers with an asterisk indicate a significant difference between the treatments within the same harvest period (Fisher test, $p<0.05$ ). Bars with the same letter between harvests (lowercase letters for the untreated plants and uppercase letters for treated plants) do not differ significantly (Tukey's test, $p>0.05$ ) 


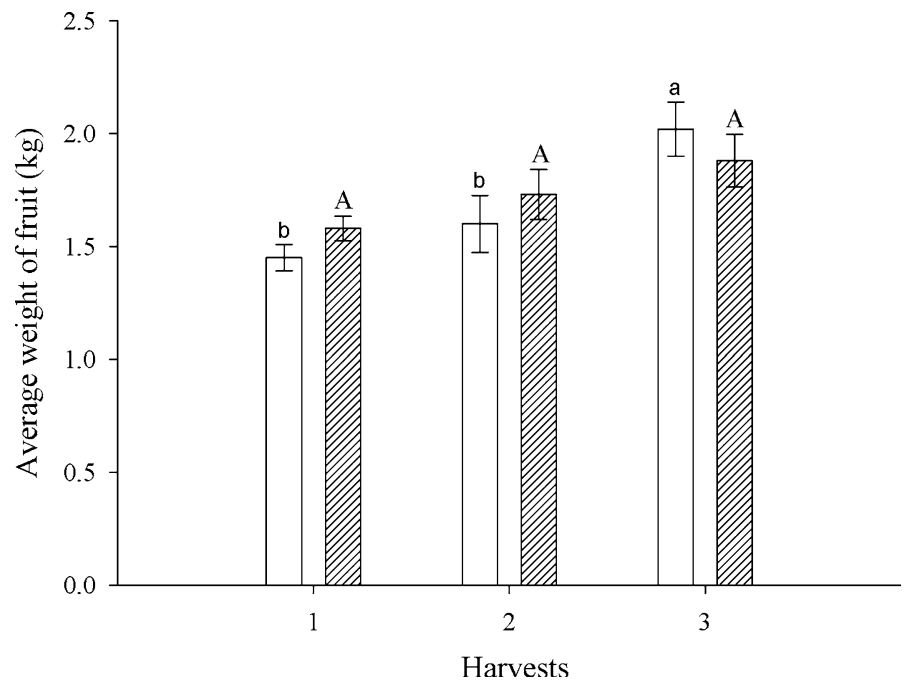

Fig. 3 Mean $( \pm$ SEM) weight $(\mathrm{kg})$ per fruit during 3 non-successive harvests. The white bars represent untreated plants, and the hatched bars represent treated plants. Treatments within a harvest do not differ significantly (Fisher test, $p>0.05$ ). Bars with the same letter between harvests (lowercase letters for the untreated plants and uppercase letters for treated plants) do not differ significantly (Tukey's test, $p>0.05$ )

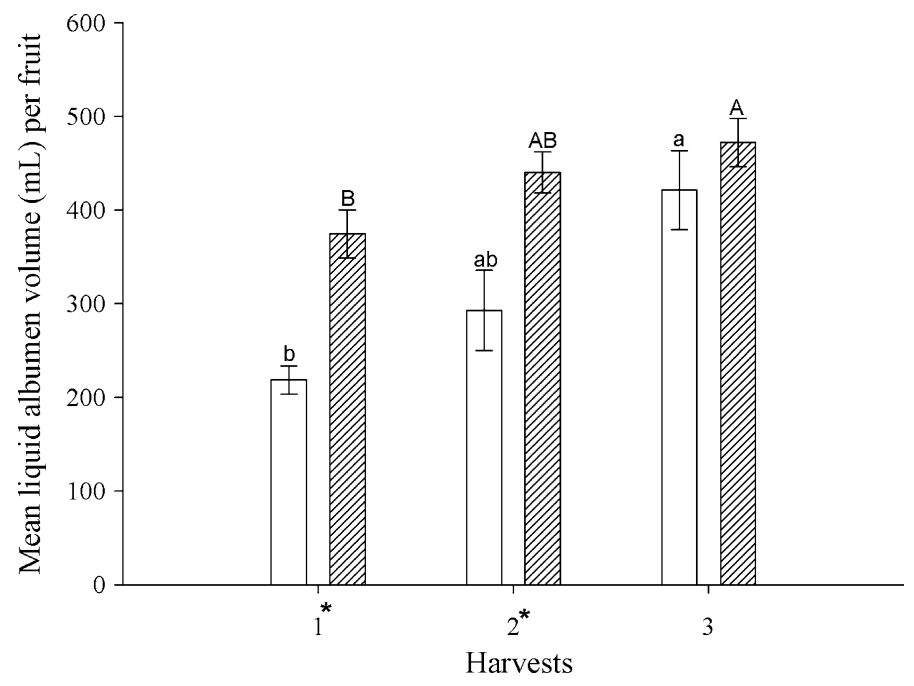

Fig. 4 Mean $( \pm$ SEM) liquid albumen volume $(\mathrm{mL})$ per fruit during 3 non-successive harvests. The white bars represent untreated plants, and the hatched bars represent treated plants. Numbers with an asterisk indicate a significant difference between the treatments within a harvest (Fisher test, $p<0.05$ ). Bars with the same letter between harvests (lowercase letters for the untreated plants and uppercase letters for treated plants) do not differ significantly (Tukey's test, $p>0.05$ )

albumen volume per fruit ( $r=0.71, n=28, P<0.0001$; Fig. 5B). However, the opposite occurred in the plants with sprayed bunches (mean number of fruits per bunch and mean fruit weight per bunch: $r=-0.64, n=27, P=0.0002$, Fig. $5 \mathrm{~A}$; and number of fruits per 

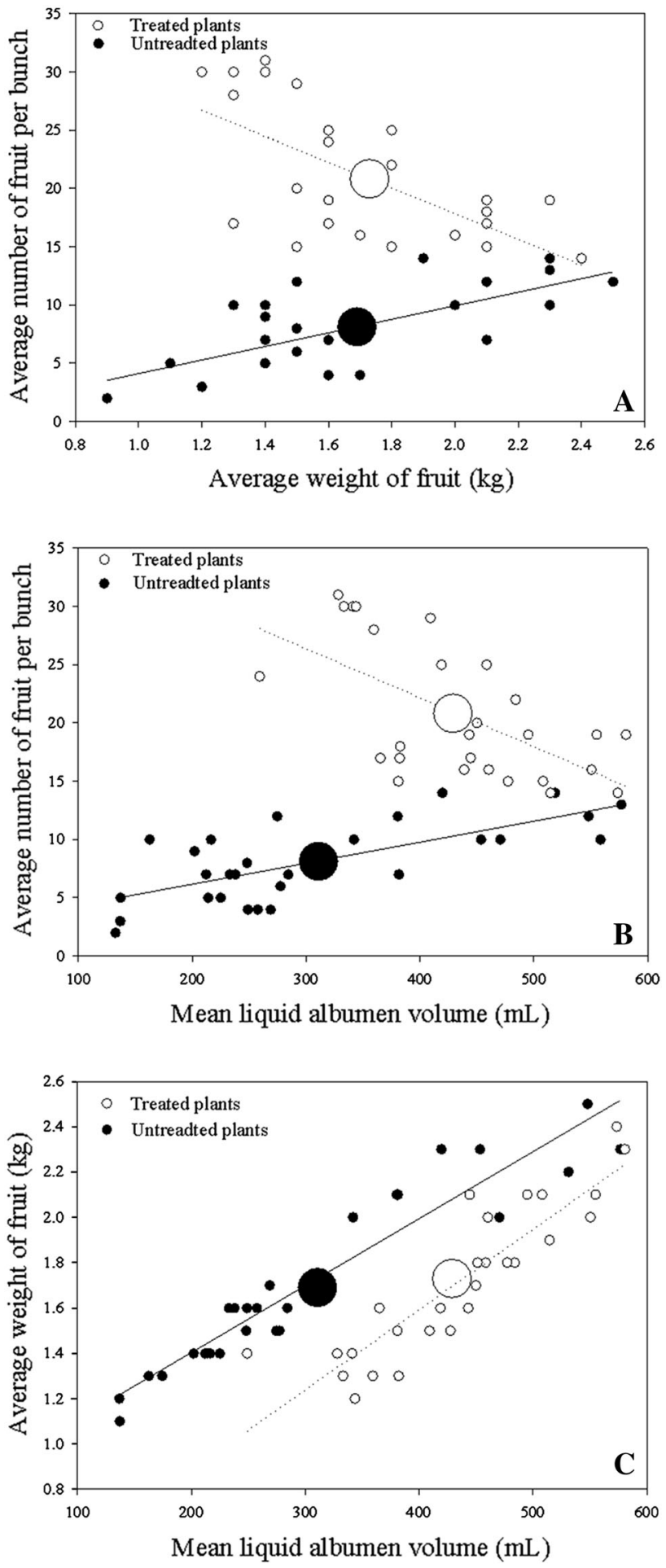
Fig. 5 Linear correlations: A between the mean number of fruits per bunch and mean weight per fruit, $\mathbf{B}$ between the mean number of fruits per bunch and mean liquid albumen volume per fruit, and $\mathbf{C}$ between mean weight and mean liquid albumen volume per fruit. The white and black circles refer to treated and untreated plants, respectively. The large circles correspond to the mean

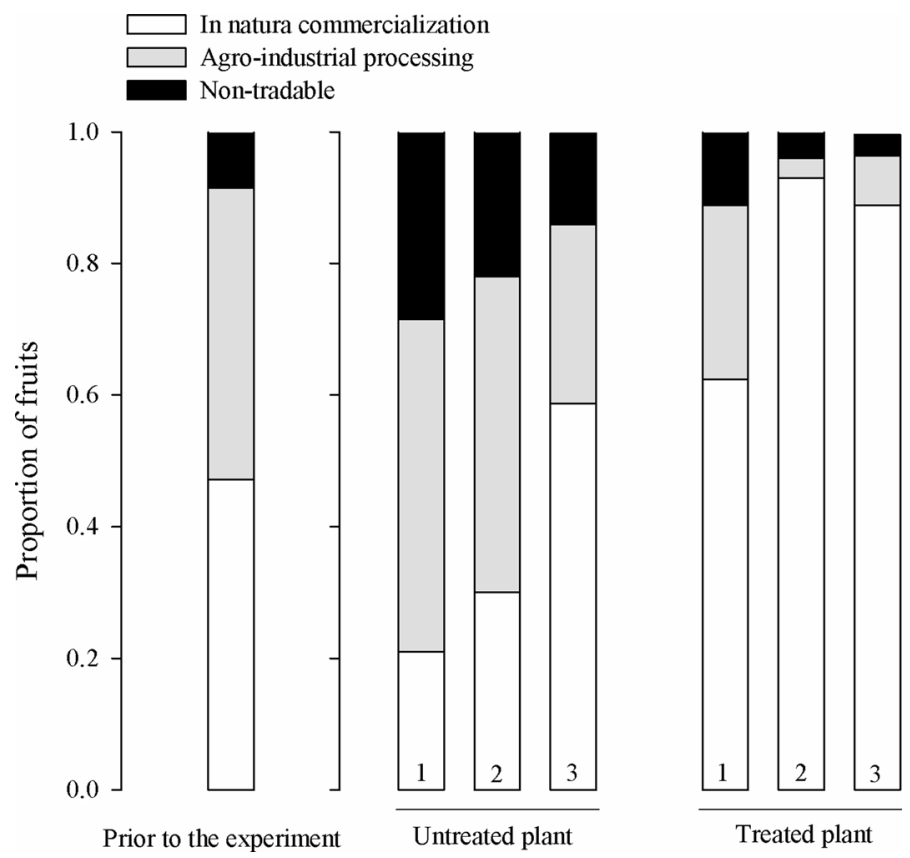

Fig. 6 Proportion of fruits categorised as intended for fresh market (white bars), intended for industrial processing (grey bars), and non-marketable (black bars). Comparison between treatments for each evaluation period (pre-evaluation and harvests 1,2, and 3)

bunch and liquid albumen volume per fruit: $r=-0.60, n=28, P=0.0006$, Fig. 5B). For both plant subgroups, significantly positive correlations were observed between mean fruit weight per bunch and liquid albumen volume/fruit (untreated plants: $r=0.91, n=30$, $P<0.0001$; treated plants: $r=0.79, \mathrm{n}=30, P=0.0001$; Fig. 5C).

For all harvests after the beginning of the spraying, the sprayed plants exhibited higher proportions of fruit intended for fresh market than the unsprayed plants $\left(\chi^{2}>5.36, d f=1\right.$, $P<0.021$; Fig. 6), whereas the opposite occurred for the fruit intended for industrial processing $\left(\chi^{2}>6.11, d f=1, P<0.013\right.$; Fig. 6). The unsprayed plants also exhibited higher proportions of non-marketable fruit $\left(\chi^{2}>4.60, d f=1, P<0.032\right.$; Fig. 6).

\section{Evaluation of the costs associated with chemical control}

The total estimated cost of spraying 1 hectare (205 plants) of coconut palms over a 1-year period was BRL 4527.00, wherein the operational costs (machine hours and worker wages) accounted for $86.5 \%$ of this total, and the purchase of inputs represented $13.5 \%$ of this total. The details are shown in Table 1.

Considering the three harvests performed during the study, the sprayed plants exhibited on average 20.7 fruits per bunch harvested with a mean of $0.357 \mathrm{~L}$ of liquid albumen per 
Table 1 Costs of abamectin spraying at the treated site (chemical control) of green dwarf coconut palm cultivation, for 1 ha within a 1-year period. Costs were zero at the untreated site

\begin{tabular}{lc}
\hline Expenses (labour and inputs) & Cost (BRL) \\
\hline BRL/machine hour & 2925.00 \\
Daily wages & 990.00 \\
Mineral oil & 243.00 \\
Vertimec & 369.00 \\
Total & 4527.00 \\
\hline
\end{tabular}

Table 2 Net profit (NP) from two sites of green dwarf coconut palm cultivation: treated site (chemical control) and untreated site, for 1 ha within a 1-year period

\begin{tabular}{|c|c|c|c|c|c|c|}
\hline \multirow[t]{2}{*}{ Destination/Sale } & \multicolumn{3}{|l|}{ Treated } & \multicolumn{3}{|c|}{ Untreated } \\
\hline & $\begin{array}{l}\text { No. of } \\
\text { fruits }\end{array}$ & Price (BRL) & $\begin{array}{l}\text { Partial NP } \\
(\mathrm{BRL})\end{array}$ & $\begin{array}{l}\text { No. of } \\
\text { fruits }\end{array}$ & Price (BRL) & $\begin{array}{l}\text { Partial NP } \\
\text { (BRL) }\end{array}$ \\
\hline Fresh market & 3444 & $0.45 /$ fruit & $27,896.4$ & 697 & $0.45 /$ fruit & 5645.7 \\
\hline Industrial processing & 594.5 & $0.75 / \mathrm{L}$ albumen & 2865.2 & 615 & $0.75 / \mathrm{L}$ albumen & 2465.8 \\
\hline Total NP (BRL) & $30,761.60$ & & & 8111.50 & & \\
\hline
\end{tabular}

fruit. Of these fruits, $81 \%$ were intended for fresh market (BRL $0.45 /$ fruit), $14 \%$ were intended for industrial processing (BRL $0.75 / \mathrm{L}$ of liquid albumen), and $5 \%$ were discarded. A gross profit of BRL 30,761.59 was generated (Table 2). The net profit obtained from the difference between total gross profit and the costs involved in spraying was BRL $26,235.00$. The unsprayed plants exhibited on average 8.1 fruits per bunch harvested with a mean value of $0.297 \mathrm{~L}$ of liquid albumen per fruit. Of these fruits, $43 \%$ were intended for fresh market (BRL 0.45/fruit), $37 \%$ were intended for industrial processing (BRL 0.75/L of liquid albumen), and $21 \%$ were discarded, generating a net profit (as there was no costs from spraying) of BRL 8111.50. Thus, the difference between the profit of the treated site and the untreated site was BRL 18,123.50; this value represents a $69.1 \%$ higher profit from the treated site.

\section{Discussion}

The results of this study provide evidence consistent with the losses caused by A. guerreronis, which consist of reduced number of fruits, reduced liquid albumen volume, and compromised final market destination of the fruits with consequent reduced economic benefit for the farmers. Additionally, the economic viability of chemically controlling this pest in green dwarf coconut palm crops was confirmed.

There is variation in the estimated losses caused by A. guerreronis in the scientific literature. This variation is partially explained by the use of different methods, which hinders direct comparison between studies (Navia et al. 2013). Additionally, the percentage of losses may vary due to fruit age, plant variety, climatic conditions, the presence of predatory mites, control practices, and marketing (Mariau and Julia 1970; Julia and Mariau 1979; Suarez 1991; Seguni 2000; Ramaraju et al. 2005; Howard 2006; Fernando and 
Aratchige 2010; Negloh et al. 2011). The pattern of A. guerreronis damage can be affected by the fruit's bract arrangement (Howard 2006), which is a characteristic that can be explored in the search for resistant varieties. Lawson-Balagbo et al. (2008) found that long periods of drought and high temperature appear to be decisive factors in A. guerreronis occurrence and establishment, with a lower incidence of this pest in regions with high rainfall. Regular rainfall most likely reduces the chance that a mite will successfully reach a new fruit during the dispersal process (Howard et al. 1990). Predator presence is another factor that may affect the losses caused by A. guerreronis because it is known that acarine fauna are variable in different regions and that some predators may be more efficient. The predators Neoseiulus baraki (Athias-Henriot) and N. paspalivorus (De Leon) (Acari: Phytoseiidae) appear to be morphologically adapted to living under the perianth, and thus, they are the most skilled natural enemies of A. guerreronis (Lawson-Balagbo et al. 2008; Lima et al. 2012; Melo et al. 2015). Clear trends have been observed in the distribution of these predators according to prevailing climatic factors, with $N$. paspalivorus predominating in dry regions and $N$. baraki predominating in humid regions (Lawson-Balagbo et al. 2008). These predators do not occur in regions with milder temperatures (Oliveira et al. 2012; Souza et al. 2012), such as the extreme south of Bahia and São Paulo (Brazil).

A decrease in the number of fruits due to abortion is one of the problems associated with A. guerreronis attack (Doreste 1968; Nair 2002; Wickramananda et al. 2007). In the present study, A. guerreronis reduced the number of fruits by $60 \%$ for the green dwarf variety. Moore et al. (1989) recorded a decrease in the number of fruits of $31 \%$ in St. Lucia (Caribbean). In Sri Lanka, $2.9 \%$ of the losses were due to premature fruit drop (Wickramananda et al. 2007). Even when abortion does not occur, the fruits that remain in the bunch can suffer decreases in liquid albumen volume, weight, and size (Moore et al. 1989; Haq et al. 2002; Paul and Mathew 2002). Few studies have quantified losses in liquid albumen volume (Ramaraju et al. 2005) given that most coconut-producing countries of the Eastern Hemisphere, accounting for $84 \%$ of the global production (FAO 2012), produce this crop to sell the solid albumen. In this study, there was a $28 \%$ reduction in liquid albumen volume in the unsprayed plants infested with A. guerreronis. Losses in liquid albumen volume have also been found in India, reaching a $67 \%$ decrease (Ramaraju et al. 2005).

The green dwarf variety is grown to sell its liquid albumen for raw consumption or to industries that bottle it. In regard to sale for raw consumption, the outer appearance of the fruit is essential. Damage caused by A. guerreronis affects the fruit's aesthetics, and depending on its intensity, it can compromise its sale and even its industrial processing because the necrotic areas hinder the penetration of machinery into the fruit to remove the liquid albumen. Fruits with extensive necrotic areas caused by A. guerreronis are usually rejected by distributors, making their sale entirely unfeasible. In this study, $81 \%$ of the fruits from plants with abamectin-sprayed bunches were classified as intended for fresh market. In contrast, only $43 \%$ of the fruits from plants with unsprayed bunches were classified in this category, in which the market value is higher than in the other categories. The lack of spraying allowed for A. guerreronis population growth, causing reduced market value of the product as shown by the reduced number of fruits intended for fresh market and the increased number of fruits intended for industrial processing and nonmarketable fruits. Thus, it can be concluded that A. guerreronis control provided higher profitability from marketing the fruit.

The present study shows that $A$. guerreronis damage may alter natural correlations existing in coconut palm plants. Coconut palms with low A. guerreronis infestations (treated plants) exhibit negative correlations between number of fruits harvested and fruit 
weight and between number of fruits harvested and liquid albumen volume, whereas the opposite (positive correlations) is observed in plants infested with A. guerreronis. This variation can be explained by analysing the distribution of resources assimilated by the plant among its fruits. Sprayed plants (lower A. guerreronis infestations) exhibit a higher number of fruits than unsprayed plants (higher A. guerreronis infestations). Therefore, fruits from the sprayed plants tend to allocate fewer resources to weight gain and liquid albumen volume for each fruit because the resource have to be shared by a higher number of fruits. Evidently, the opposite is valid for plants with higher A. guerreronis attack. However, although there were negative correlations for the sprayed plants, they exhibited higher liquid albumen volume than the unsprayed plants. It is noteworthy that plants under intense A. guerreronis attack most likely have fewer resources to distribute among their fruits because part of these resources may be used for their defence (direct or indirect) against mite attack. It is known that coconut palms under A. guerreronis attack release volatiles, which are detected by some A. guerreronis-controlling agents such as the predatory mites N. baraki and Proctolaelaps bickleyi (Bram) (Melo et al. 2011). One way of attempting to overcome these negative correlations in treated plants and in plants with A. guerreronis populations under control is by fruit thinning.

Although some studies have shown that chemical control is an effective technique for A. guerreronis control (Mariau and Tchibozo 1973; Cabrera 1991; Ramaraju et al. 2002; Muthiah et al. 2001; Moreira and Nascimento 2002; Melo et al. 2012), there are no studies documenting the economic viability of using this method. In seeking to fill this gap in knowledge, the costs of $A$. guerreronis control were quantified in this study, and the viability of using abamectin to control this pest was also assessed. The results of this study demonstrate that the profit was $69.1 \%$ higher in the abamectin-treated site than at the untreated site, which corresponds to a difference of approximately BRL 18,123.50 in net profit per hectare within a 1-year period for the treated site compared to the untreated site. Based on these results, it can be affirmed that chemical control with abamectin in green dwarf coconut palm crops is economically feasible and allows farmers to achieve high profit margins. However, these results do not apply to other varieties (hybrids and giants) due to differences in plant size, number of fruits produced per plant, and market destination of the fruit, which can make this control method unfeasible. Additionally, irrigated plants produce bunches over a short time interval, which is not the reality for most of the crops and can reduce the economic return. A recent study suggests that increased application intervals can reduce the control costs and enable the use of chemical control in other varieties, but the application interval should be further investigated (Melo et al. 2012).

The high loss rates caused by A. guerreronis found in this study show the severity of the problem caused by this pest and the need to control it. Chemical control was efficient for the green dwarf variety, allowing plants to produce higher numbers of fruits with greater liquid albumen volume and with higher aesthetics (enabling most of the fruit to be categorised as intended for fresh market) compared to the unsprayed plants. Thus, chemical control of A. guerreronis provided higher profitability when selling the fruits, constituting a lucrative method for farmers. However, more studies should be conducted to investigate the viability of this method in other $C$. nucifera varieties.

Acknowledgments To Anderson Puker (Universidade Federal de Viçosa, Viçosa, Minas Gerais, Brazil) for fruitful comments that improved this paper. To the Programa de Apoio a Planos de Reestruturação e Expansão das Universidades Federais-REUNI/Coordenação de Aperfeiçoamento de Pessoal de Nível Superior-CAPES for the Doctoral scholarship given to the first author. To the Conselho Nacional de Desenvolvimento Científico e Tecnológico—CNPq and the Fundação de Amparo à Ciência e Tecnologia do 
Estado de Pernambuco-FACEPE for financial support for conducting the study. To Embrapa Semiárido (Petrolina, Pernambuco, Brazil) for logistical support.

\section{References}

Aragão WM, Resende JM, Cruz EMO, Reis CS, Saggin Junior OJ, Alencar JA, Moreira WA, Paula FR, Lima Filho JMP (2002) Fruto do coqueiro para consumo natural. In: Aragão WM (ed) Coco: Póscolheita. Embrapa Tabuleiros Costeiros, Aracaju, pp 19-25

Cabrera RI (1991) El ácaro del cocotero Eriophyes guerreronis su importancia económica y métodos de lucha. Estación Nacional de Sanidad de los Cítricos y Otros Frutales, Habana

Cardona IZ, Potes AS (1971) La ronã o escorión de los frutos del cocotero (Cocos nucifera L.) en Colômbia. Acta Agron 21:133-139

Cuenca MAG, Martins CR, Jesus Filho LA (2011) Estatística de produção. (http://www.agencia.cnptia. embrapa.br/gestor/coco/arvore/CONT000fo7hz6ox02wyiv8065610d6ky3ary.html). Accessed 15 July 2015

Doreste SE (1968) El ácaro de la flor del cocotero (Aceria guerreronis Keifer) en Venezuela. Agron Trop $18: 370-386$

FAO (2012) Food and Agriculture Organization (United Nations). Agriculture database. (http://www.http:// faostat3.fao.org/faostatgateway/go/to/download/Q/QC/E). Accessed 10 June 2015

Fernando LCP, Aratchige NS (2010) Status of coconut mite Aceria guerreronis and biological control research in Sri Lanka. In: Sabelis MW, Bruin J (eds) Trends in acarology. Springer, Amsterdam, pp 379-384

Fernando LCP, Chandrasiri KAS (2010) Effectiveness of spraying vegetable oil-sulphur emulsion to manage coconut mite, Aceria guerreronis. In: Dharmakeerthi RS, Senevirathna AMWK (eds) Proceedings of the third symposium on plantation crop research-Stakeholder empowerment through technological advances. Rubber Research Institute of Sri Lanka, Dartonfield, Agalawatte, pp 241-250

Fernando LCP, Wickramanada IR, Aratchige NS (2002) Status of coconut mite, Aceria guerreronis in Sri Lanka. In: Fernando LCP, de Moraes GJ, Wickramanada IR (eds) Proceedings of the International Workshop on Coconut Mite (Aceria guerreronis). Coconut Research Institute, Lunuwila, pp 1-8

Foale M (2003) The coconut odyssey: the bounteous possibilities of the tree of life. ACIAR Monograph, Canberra

Galvão AS, Gondim MGC Jr, Michereff ESJ (2008) Escala diagramática de dano de Aceria guerreronis Keifer (Acari: Eriophyidae) em Coqueiro. Neotrop Entomol 6:723-728

Galvão AS, Gondim MGC Jr, de Moraes GJ, Melo JWS (2011) Distribution of Aceria guerreronis and Neoseiulus baraki among and within coconut bunches in northeast Brazil. Exp Appl Acarol 54:373-384

Haq MA, Sumangala K, Ramani N (2002) Coconut mite invasion, injury and distribution. In: Fernando LCP, de Moraes GJ, Wickramananda IR (eds) Proceedings of the International Workshop on Coconut Mite (Aceria guerreronis). Coconut Research Institute, Lunuwila, pp 41-49

Hernández RF (1977) Combate químico del eriófido del cocotero Aceria (Eriophyes) guerreronis (K.) en la Costa de Guerrero. Agric Tec México 4:23-38

Howard FW (2006) Featured creatures. (http://entnemdept.ufl.edu/creatures/orn/palms/Aceria_guerreronis. htm). Accessed 03 June 2015

Howard FW, Abreu Rodríguez E, Denmark HA (1990) Geographical and seasonal distribution of the coconut mite, Aceria guerreronis (Acari: Eriophyidae), in Puerto Rico and Florida, USA. J Agric Univ P R 74:237-251

Julia JF, Mariau D (1979) Nouvelles recherché en Côte d'Ivoire sur Eriophyes guerreronis K., acarien ravageur des noix du cocotier. Oléagineux 34:181-189

Kottek M, Grieser J, Beck C, Rudolf B, Rubel F (2006) World map of the Köppen-Geiger climate classification updated. Meteorol Z 15:259-263

Lawson-Balagbo LM, Gondim MGC Jr, de Moraes GJ, Hana R, Schausberger P (2007) Refuge use by the coconut mite Aceria guerreronis: fine scale distribution and association with other mites under the perianth. Biol Control 43:102-110

Lawson-Balagbo LM, Gondim MGC Jr, de Moraes GJ, Hanna R, Schausberger P (2008) Exploration of the acarine fauna on coconut palm in Brazil with emphasis on Aceria guerreronis (Acari: Eriophyidae) and its natural enemies. Bull Entomol Res 98:83-96

Lima DB, Melo JWS, Gondim MGC Jr, de Moraes GJ (2012) Limitations of Neoseiulus baraki and Proctolaelaps bickleyi as control agents of Aceria guerreronis. Exp Appl Acarol 56:233-246 
Mariau D, Julia JF (1970) L'acariose a Aceria guerreronis (Keifer), ravageur du cocotier. Oléagineux 25:459-464

Mariau D, Tchibozo HM (1973) Essais de lute chimique contre Aceria guerreronis (Keifer). Oléagineux 28:133-135

Martin CR, Jesus LA Jr (2011) Evolução da produção de coco no Brasil e o comércio internacional: panorama 2010. Embrapa Tabuleiros Costeiros, Aracaju

Melo JWS, Lima DB, Pallini A, Oliveira JEM, Gondim MGC Jr (2011) Olfactory response of predatory mites to vegetative and reproductive parts of coconut palm infested by Aceria guerreronis. Exp Appl Acarol 55:191-202

Melo JWS, Domingos CA, Pallini A, Oliveira JEM, Gondim MGC Jr (2012) Removal of bunches or spikelets is not effective for the control of Aceria guerreronis. HortScience 47:626-630

Melo JWS, Lima DB, Staudacher H, Silva FR, Gondim MGC Jr, Sabelis MW (2015) Evidence of Amblyseius largoensis and Euseius alatus as biological control agent of Aceria guerreronis. Exp Appl Acarol 67:411-421

Moore D (2000) Non-chemical control of Aceria guerreronis on coconuts. Biocontrol News Inf 21:83-87

Moore D, Howard FW (1996) Coconuts. In: Lindquist EE, Sabelis MW, Bruin J (eds) Eriophyoid mites: their biology, natural enemies and control. Elsevier, Amsterdam, pp 561-570

Moore D, Alexander L, Hall RA (1989) The coconut mite, Eriophyes guerreronis Keifer in St Lucia yield losses and attempts to control it with acaricide, polybutene and Hirsutella fungus. Trop Pest Manag 35:83-89

Moreira JOT, Nascimento ARP (2002) Avaliação da eficiência de acaricidas isolados e em mistura no controle do ácaro-da-necrose-do-coqueiro Aceria guerreronis Keifer, 1965 (Prostigmata: Eriophyidae) no Vale do São Francisco. Rev Bras Frutic 24:72-76

Muthiah C, Bhaskaran R, Kannaiyan S (2001) Bioecology and control of eriophyid mite of coconut: an Indian experience. Planter 77:255-263

Nair CPR (2002) Status of eriophyid mite Aceria guerreronis Keifer in India. In: Fernando LCP, de Moraes GJ, Wickramananda IR (eds) Proceedings of the international workshop on coconut mite (Aceria guerreronis). Coconut Research Institute, Lunuwila, pp 9-12

Navia D, Gondim MGC Jr, Aratchige NS, de Moraes GJ (2013) A review of the status of the coconut mite, Aceria guerreronis (Acari: Eriophyidae), a major tropical mite pest. Exp Appl Acarol 59:67-94

Negloh K, Hanna R, Schausberger P (2011) The coconut mite, Aceria guerreronis, in Benim and Tanzania: occurrence, damage and associated acarine fauna. Exp Appl Acarol 55:361-374

Oliveira DC, de Moraes GJ, Dias CTS (2012) Status of Aceria guerreronis Keifer (Acari: Eriophyidae) as a pest of coconut in the state of São Paulo, Brazil. Neotrop Entomol 41:315-323

Paul A, Mathew TB (2002) Loss of husk, quality of fiber and coir due to infestation of coconut eriophyid mite (Aceria guerreronis Keifer). J Plant Crop 30:58-60

Ramaraju K, Natarajan K, Babu PCS, Palnisamy S, Rabindra RJ (2002) Studies on coconut eriophyid mite, Aceria guerreronis Keifer in Tamil Nadu, India. In: Fernando LCP, de Moraes GJ, Wickramananda IR (eds) Proceedings of the International Workshop on Coconut Mite (Aceria guerreronis). Coconut Research Institute, Lunuwila, pp 13-31

Ramaraju K, Palaniswamy S, Annakodi P, Varadarajan MK, Muthukumar M, Bhaskaran V (2005) Impact of coconut eriophyid mite, Aceria guerreronis K. (Acari: Eriophyidae) on the yield parameters of coconut. Indian Coconut J 25:12-15

SAS Institute (2002) SAS/STAT User's guide, version 8.02, TS level 2MO. SAS Institute, Cary

Seguni Z (2000) Incidence, distribution and economic importance of the coconut eriophyid mite, Aceria guerreronis Keifer in Tanzanian coconut based cropping systems. In: Fernando LCP, de Moraes GJ, Wickramananda IR (eds) Proceedings of the international workshop on coconut mite (Aceria guerreronis). Coconut Research Institute, Lunuwila, p 10

Silva VF, França GV, Melo JWS, Gondim Jr MGC (2013) Brácteas de frutos de coco como fator limitante a ação de acaricidas sobre Aceria guerreronis Keifer. In: IV Simpósio Brasileiro de Acarologia. Bento Gonçalves

Souza IV, Gondim MGC Jr, Ramos ALR, Santos EA, Ferraz MIF, Oliveira AR (2012) Population dynamics of Aceria guerreronis (Acari: Eriophyidae) and other mites associated with coconut fruits in Una, state of Bahia, northeastern Brazil. Exp Appl Acarol 58:221-233

Suarez A (1991) Distribución y evaluación de danõs del acaro Eriophyes guerreronis en plantaciones de cocotero de la region de Baracoa. Prot Plant 1:75-81

Wickramananda IR, Peiris TSG, Fernando MT, Fernando LCP, Edgington S (2007) Impact of the coconut mite (Aceria guerreronis Keifer) on the coconut industry in Sri Lanka. Cord 23:1-16 